\title{
POSTAWY WOBEC NIEPEŁNOSPRAWNOŚCI FIZYCZNEJ W OKRESIE ŚREDNIOWIECZA
}

\section{ATTITUDES TOWARDS PHYSICAL DISABILITY IN THE MIDDLE AGES}

\author{
Zakład Nauk Humanistycznych w Medycynie Pomorskiego Uniwersytetu Medycznego w Szczecinie \\ ul. Żołnierska 48, 71-210 Szczecin \\ Kierownik: dr n. hum. Tadeusz Dyk \\ ${ }^{1}$ Doktorant Wydziału Historycznego Uniwersytetu im. A. Mickiewicza w Poznaniu \\ ul. Św. Marcin 78, 61-809 Poznań
}

\begin{abstract}
Summary
The article describes attitudes to disability and physically disabled people, taking into account the aspect of ethical and social location, what physically disabled meant in societies, and ways to solve the problems of disability. The article is based on studies of disability and historical sources. Christ's attitude shown in the Gospels changed the traditional cultures of the ancient treatment of disability in terms of it being seen as a penalty of the divine. The development of Christianity caused a gradual expansion of the ideas of charity, at the same time stepping up care and material support to all those physically disabled in need. Care of the disabled is based mostly on charity. Church activities supported, by the structure of the State and private individuals, was of paramount importance. Medieval society felt responsible for disabled people.

K e y w o r d s: physical disability - leprosy - middle ages - Christianity - alms - hospital.

\section{Streszczenie}

W pracy opisano stosunek do niepełnosprawności i niepełnosprawnych fizycznie, biorąc pod uwagę aspekt etyczny i społeczny, obejmujące miejsce, jakie niepełnosprawni fizycznie zajmowali w ówczesnych społeczeństwach oraz sposoby rozwiązania problemu niepełnosprawności. W pracy autorzy oparli się na opracowaniach niepełnosprawności oraz źródłach historycznych.
\end{abstract}

Ukazana w ewangeliach postawa Chrystusa zmieniła tradycyjne w kulturach starożytnych traktowanie niepełnosprawności w kategoriach kary boskiej. Rozwój chrześcijaństwa spowodował stopniowe rozszerzanie się idei miłosierdzia, wpływając jednocześnie na zintensyfikowanie opieki i wsparcie materialne wobec wszystkich potrzebujących, w tym niepełnosprawnych fizycznie. Opieka nad niepełnosprawnymi opierała się głównie na dobroczynności. Zasadnicze znaczenie miała tu działalność kościoła wspieranego przez struktury państwowe oraz osoby prywatne. Społeczeństwo średniowieczne czuło się więc odpowiedzialne za niepełnosprawnych.

H a s $\nmid$ a: niepełnosprawność fizyczna - trąd - średniowiecze - chrześcijaństwo - jałmużna - szpital.

\section{Tradycyjny paradygmat niepełnosprawności}

Problem ludzi niepełnosprawnych istnieje od początków cywilizacji ludzkiej, a pojęcie niepełnosprawności ewoluuje wraz z jej rozwojem. Natura warunkuje to, że człowiek w odróżnieniu od zwierząt posiada pewien poziom empatii pozwalający nie pozostawać obojętnym na los bezradnych przedstawicieli tego samego gatunku. Znaczenie mają również i inne czynniki wpływające na stosunek do niepełnosprawnych. Można do nich zaliczyć religię i wzorce kulturowe obowiązujące w społeczeństwie.

Starożytny przekaz kulturowy (m.in. mitologia) łączył niepełnosprawność z cechami negatywnymi. Ludzie niepełnosprawni byli stygmatyzowani we wszystkich 
cywilizacjach antycznych. Wynikało to m.in. z kultu pięknego ciała i sprawności fizycznej oraz przekonania o niewielkiej wartości życia osoby niepełnosprawnej.

Źródła dotyczące historii starożytnej ukazują bezwzględne podejście do dzieci, które urodziły się jako niepełnosprawne. Zarówno w Sparcie, w Atenach, jak i w Rzymie dopuszczalne było ich zabijanie. W Sparcie, gdzie stosowano drastyczną praktykę polegającą na porzucaniu wątłych i chorych noworodków na zboczach pasma górskiego Tajgetos, o życiu dziecka decydowała rada starszych, a w Atenach i w Rzymie ojciec dziecka.

Przekaz stygmatyzujący obecny był także w starożytnym Izraelu. W datowanej na VI w. p.n.e. Księdze Kapłańskiej znajduje się przepis wykluczający osoby niepełnosprawne z posługi kapłańskiej. Czytamy w nim: „Żaden człowiek, który ma skazę, nie może się zbliżać [do ołtarza] - ani niewidomy, ani chromy, ani mający zniekształconą twarz, ani kaleka" (Kpł 21,17-18) [1]. Osoby niepełnosprawne były więc niegodne, aby składać ofiary Bogu. Ówczesna norma kulturowa stanowiła, że Bóg się odwrócił od osób dotkniętych ułomnością fizyczną lub ubóstwem. Odwrócenie to było zazwyczaj skutkiem grzechu samego człowieka lub jego przodków. Zdrowie i bogactwo z kolei świadczyło o błogosławieństwie Boga.

Pomimo negatywnego wizerunku ludzi niepełnosprawnych, nakaz religijny nie pozwalał jednak na całkowite pozostawienie ich bez opieki. W Księdze Powtórzonego Prawa czytamy więc: „Przeklęty, kto sprawia, że niewidomy błądzi na drodze. A cały lud powie: Amen" (Pwt 27,18).

Z kolei w Atenach pojawiły się początki zinstytucjonalizowanej opieki polegające na wypłacaniu corocznej renty dorosłym obywatelom niemogącym utrzymać się z powodu kalectwa.

W cywilizacjach antycznych widoczne są więc dwie przeciwstawne postawy wobec niepełnosprawności: odrzucenia oraz akceptacji i opieki nad niepełnosprawnymi.

\section{Nowotestamentowe ujęcie niepelnosprawności}

Nowy Testament przyniósł zmianę w schemacie myślowym: cierpi, bo na to zasłużył. Wśród licznych uzdrowień wymienianych w ewangelii kluczową jest scena, w której Jezus uzdrawiając niewidomego od urodzenia, mówi, że choroba nie jest wynikiem jego grzechu: „Rabbi, kto zgrzeszył, że się urodził niewidomym - on czy jego rodzice? Jezus odpowiedział: Ani on nie zgrzeszył, ani rodzice jego, ale stało się tak, aby na nim objawiły się sprawy Boże”. Czyn i słowa Jezusa kontrastują z tradycyjnie stygmatyzującą postawą faryzeuszy, którzy w dalszych wersach tego fragmentu ewangelii zwracają się do uzdrowionego i mówią: „Cały jesteś w grzechach” (J 9,2-3).

Inne sytuacje mówiące o uzdrowieniach ludzi dotkniętych niepełnosprawnością dotyczą człowieka ze sparaliżowaną ręką (Mk 3,1-6; Mt 12,9-13; Łk 6), chorego na puchlinę ( $Ł k$ 14,1-6; Mt 12,11-12), trędowatego
(Mt 8,1-4; Mk 1,40-45; Łk 5,12-16), kobiety cierpiącej na krwotok (Mt 9,20-22; Mk 5,25-34; Łk 8,43-48), sparaliżowanego nad sadzawką (J 5,1-18), dwóch niewidomych (Mt 9,27-31), kobiety uzdrowionej w szabat (Łk 13,10-17), głuchoniemego uzdrowionego w Dekapolis (Mk 7,31-37) niewidomego uzdrowionego w Betsaidzie (Mk 8,22-26), epileptyka (Mt 17,14-21; Mk 9,14-29; Łk 9,37-49), uzdrowienia w Genezaret (Mt 14,34-36; Mk 6,53-56), dziesięciu trędowatych (Łk 17,11-19), niewidomych uzdrowionych pod Jerychem (Mt 20,29-34; Mk 10,46-52; Łk 18,35-43). Choć kalectwo nie jest uważane przez Jezusa za wynik grzesznego życia, to uzdrowieniu towarzyszy też odpuszczanie grzechów - uzdrowienie paralityka w Kafarnaum (Mt 9,1-8; Mk 2,1-12), uwolnienia z opętania niewidomego i niemego (Mt 12,22-28; Mk 3,20-30) oraz niemego (Mt 9,32-34; Łk 11,14-23).

W cudownych uzdrowieniach samo wyleczenie pełni więc rolę drugoplanowa, jest niejako znakiem, który ma potwierdzać boskość Chrystusa, ale przede wszystkim ukazywać go jako zbawiciela mającego moc odpuszczenia grzechów. Leczenie ciała towarzyszy więc leczeniu duszy. Jezus Chrystus przez uzdrowienie niewidomego zrywa z tradycyjnym podejściem, stygmatyzującym niepełnosprawnych, a ponadto daje przykład miłosiernego postępowania wobec nich i udzielania im fizycznej pomocy.

Według nowo tworzącej się chrześcijańskiej myśli filozoficznej, ludzie dotknięci niepełnosprawnością nie są już przeklęci przez Boga. Nowe postrzeganie niepełnosprawności znalazło odzwierciedlenie w poglądach dotyczących przyczyn chorób i kalectwa. Średniowieczni teologowie głosili, że człowiek może być nimi dotknięty nie tylko po to, aby się nawrócić i zostać sprowadzonym na właściwą drogę, ale także w celu głoszenia chwały bożej w przypadku ozdrowienia [2]. Choroba i niepełnosprawność są więc dopuszczone przez Boga, lecz nie stanowią już kary za grzechy. Co więcej, są one nieodłączną częścią zbawczego planu Boga wobec człowieka. Cierpienie nabiera więc sensu i wartości przez uwrażliwienie cierpiącego na sferę duchową oraz zbliżanie zarówno chorego, jak i niepełnosprawnego oraz jego bliskich do Boga [3]. Nowy sposób postrzegania choroby jest nawiązaniem do starotestamentowego obrazu cierpienia Hioba dotkniętego, oprócz różnych nieszczęść życiowych, również kalectwem.

\section{Przypadki niepełnosprawności}

Odkrycia archeologiczne dostarczają cennych informacji dotyczących przypadków niepełnosprawności fizycznej występujących w średniowieczu. Przypadki te były wynikiem zarówno chorób wrodzonych, jak i nabytych.

Wśród licznych średniowiecznych stanowisk archeologicznych występujących na terenie Polski, największą ilość pochówków (> 3 tys.) pochodzących z okresu pomiędzy X a XIV w. znaleziono w okolicach Kałdusa i Gruczna (woj. kujawsko-pomorskie). Znalezione szkielety zostały 
poddane badaniom antropologicznym. Wykazały one, że częstą przyczyną niepełnosprawności były schorzenia układu kostnego, m.in. zmiany zwyrodnieniowe kręgosłupa oraz stawów obwodowych, a także stany zapalne i przewlekłe, zmiany atroficzne okostnej [4]. Choroby nabyte prowadzące do niepełnosprawności były spowodowane zarówno ciężką pracą fizyczną, np. w kopalni (pylica), ale także niewłaściwą dietą i złymi warunkami higienicznymi (krzywica, szkorbut, gruźlica, anemie) czy też nieodpowiednim trybem życia (kiła).

Choroby miały też podłoże epidemiologiczne (ospa, kiła, tyfus, cholera) czy infekcyjne (wirusy, bakterie i grzyby chorobotwórcze). Przykładem mogą tu być zatrucia sporyszem (pasożytem zboża) prowadzące do przewlekłego skurczu naczyń krwionośnych i niedostatecznego ukrwienia, a w efekcie do gangreny oraz martwicy kończyn, a także do zaburzeń w układzie nerwowym powodujących epilepsje.

Wśród chorób mających podłoże genetyczne, występowały też zaburzenia sensoryczne oraz nowotwory.

Oprócz chorób najczęstszą przyczyną niepełnosprawności były urazy spowodowane licznymi walkami mającymi miejsce w średniowieczu. Należały do nich: urazy głowy i narządów (np. oka), rany cięte kończyn górnych, a zwłaszcza okolic stawów barkowych, a także urazy okolicy podstawy szyi, kręgosłupa szyjnego rdzenia kręgowego oraz liczne złamania. Obrażania te powstawały w wyniku ran ciętych, tłuczonych, miażdżonych drążących, przeszywających. Wielorakość tych ran była spowodowana stosowaniem wielu rodzajów broni: obuchowej (topory, maczugi), drzewcowej (kopie, włócznie), siecznej (miecze) [5]. Urazy bywały także wynikiem ciężkiej pracy fizycznej.

Ówczesne umiejętności chirurgiczne i prawidłowo przeprowadzone amputacje czy nawet trepanacje czaszki niejednokrotnie pozwalały ratować życie, jednak nieumiejętność radzenia sobie z infekcjami i pourazowymi stanami zapalnymi była częstą przyczyną zgonu.

\section{Formy wsparcia niepelnosprawnych}

Odkrycia archeologiczne oraz źródła pisane dostarczają także informacji dotyczących postaw ówczesnego społeczeństwa wobec osób niepełnosprawnych (w tym sposobów ich wspierania). Odnalezione pochówki osób niepełnosprawnych znajdują się najczęściej w obrębie ogólnych cmentarzy, z czego można wnioskować, że osoby te akceptowano i traktowano tak, jak zdrowych mieszkańców.

Przykładem takiego pochówku jest odkrycie w południowo-wschodniej Francji (miejscowość Beaume), gdzie na przyklasztornym cmentarzu znaleziono 20 grobów starszych osób dotkniętych niepełnosprawnością datowanych na ok. XII-XIII w. Odkrycie to może wskazywać na istnienie przy klasztorze szpitala dla osób niepełnosprawnych. Znane są także przypadki chowania zwłok na cmentarzach poza miastem, co miało miejsce w Strasburgu i dotyczyło 3 niepełnosprawnych. Może to z kolei świadczyć o tym, że pochowane tam osoby nie były jego mieszkańcami, lecz prowadziły wędrowny i żebraczy tryb życia [6].

Na postawę czynnej pomocy i rozwój opieki nad chorymi oraz niepełnosprawnymi wpłynęła chrześcijańska idea miłosierdzia. Oznaczała ona w praktyce miłość wobec bliźniego (caritas) okazaną w odniesieniu do słabego i zależnego ludzkiego ciała (infirmitas).

Naturalną była więc opieka nad niepełnosprawnymi członkami w rodzinach. Na szeroką skalę opieka ta była realizowana przez tak powszechne w wiekach średnich zakony i związane z nimi szpitale. Początkowo były one integralną częścią klasztorów, z czasem zaczęły powstawać osobne instytucje szpitalne.

Średniowieczne szpitale pełniły przede wszystkim funkcję domów opieki i przytułków, do których trafiały zazwyczaj osoby samotne. Podstawowym zadaniem szpitali było udzielanie schronienia: ubogim i chorym (syndochium), starcom (gerocontocomium) oraz sierotom (orphantoropium) [7].

Pierwsze przytułki dla najbardziej potrzebujących (chorych, ubogich), tzw. nosocomia, zaczęły powstawać już w pierwszych wiekach średniowiecza. Ich działalność była regulowana zarówno rozporządzeniami władzy cesarskiej (kodeks Justyniana z VI w. włączający przytułki do jurysdykcji kościelnej), jak i uchwałami synodów kościelnych (np. synodu w Akwizgranie z 816 r. nakazującego budować je przy każdej katedrze, siedzibie biskupiej w państwie frankońskim).

W państwie Karola Wielkiego szpitalnictwo zaczęło się rozwijać także przy klasztorach. Wśród klasztorów żeńskich opieką i pielęgnacją chorych oraz niepełnosprawnych zajmowały się beginki i klaryski. Szczególną rolę w tej opiece odegrały tzw. diakonisy, czyli świeckie zgromadzenie istniejące do VIII w. Wśród zgromadzeń męskich działalność opiekuńczą rozwijali nestorianie w Persji, bazylianie w Cezarei, a także benedyktyni na Monte Cassino.

W okresie wypraw krzyżowych powstawały natomiast zakony szpitalne opiekujące się tymi, którzy ucierpieli w walkach. Należeli do nich: joannici (rycerze szpitalni św. Jana opiekujący się chorymi psychicznie), templariusze, krzyżowcy czy zakon pod wezwaniem Ducha Świętego.

Na terenie Polski szczególną rolę w zakładaniu szpitali odegrali od XII w. benedyktyni (klasztory w Tyńcu, Sieciechowie, na Łysej Górze). Zakładali oni szpitale także poza terenem klasztorów (Nowogród Bobrzański, Żagań, Jasienica koło Szczecina).

Działalność opiekuńczą rozwijali też cystersi (opactwa w Trzebnicy, Kamieńcu, Lubiążu, Jędrzejowie, Kołbaczu, Wieleniu, Wolinie, Szczecinie), a począwszy od XII i XIII w. joannici (szpitale w Poznaniu, Wrocławiu, Kłodzku) oraz duchacy (Prądnik, Kalisz, Sandomierz). Szpitale znajdowały się też poza klasztorami, najczęściej w kanoniach (Wrocław, Sobótka, Czerwińsk, Oleśnica) oraz przy katedrach (Poznań, Włocławek, Chełmno). Były tworzone nie tylko ze środków zgromadzeń zakonnych, ale także fundowane przez możnowładców, rycerstwo i biskupów. Utrzymywane były 
z prywatnych danin, a niektóre miały regularne dochody, np. dziesięciny. $Z$ czasem zaczęto tworzyć szpitale miejskie, a niekiedy te już istniejące przechodziły na własność miasta. W Polsce to zjawisko pojawiło się w XIII w. (szpitale w Szczecinie, Kołobrzegu, Słupsku, Jaworze, Strzegomiu, Żaganiu).

Formę wsparcia dla niepełnosprawnych stanowiły też fundusze chorobowe tworzone przez cechy rzemieślnicze. Były one pierwowzorem ubezpieczeń społecznych i stanowiły realną pomoc dla członków cechów, którzy utracili zdrowie. Jednak w średniowieczu najistotniejszym wsparciem finansowym dla niepełnosprawnych była jałmużna zalecana przez doktrynę chrześcijańską, której dawanie było realnym znakiem chrześcijańskiego miłosierdzia. Jałmużna, obok postu i modlitwy, stanowiła jeden z podstawowych czynników nawrócenia i pokuty. Ludzie dawali ją, chcąc być dobrymi chrześcijaninami i w celu zapewnienia sobie zasługi w życiu wiecznym, zgodnie ze słowami z ewangelii: „Jeśli wasza sprawiedliwość nie będzie większa niż uczonych w Piśmie i faryzeuszów, nie wejdziecie do królestwa niebieskiego" (Mt 5,20).

Regularnym rozdawaniem jałmużny (eleemosina consueta) zajmowały się wspominane zakony, których reguła nakazywała troskę m.in. o ubogich i chorych. Jałmużna, oprócz dawania pieniędzy, przyjmowała postać materialną (rozdawanie chleba, żywności i wina) [8]. Niektórzy średniowieczni możnowładcy, oprócz zaopatrywania szpitali w żywność i odzież, brali osoby niepełnosprawne na utrzymanie.

Dawanie jałmużny, obok aspektu pozytywnego, czyli pomocy potrzebującym, miało też wpływ na rozwój żebractwa, które było powszechnie akceptowane, ale zgodnie ze słowami św. Pawła („,kto nie chce pracować, niech też nie je”) akceptacja dotyczyła jednak tylko niezdolnych do pracy zarobkowej z powodu niepełnosprawności lub wieku (2 Tes 3,10).

Nakaz królewski w XIV-wiecznej Francji głosił, że ,prawo do jałmużny mają tylko ślepi, ułomni i niezdolni do pracy nędzarze" [9]. Kościół potępiał więc jałmużnę udzieloną żebrakowi niezasługującemu na wsparcie, jako szkodzącą zarówno ofiarodawcy, jak i temu, który otrzymał jałmużnę [10].

Żebrzący prowadzili wędrowny tryb życia, szukając nowych dobroczyńców, czasem pielgrzymowali do sanktuariów, chcąc być uzdrowionymi. Niejednokrotnie jednak żebractwo stawało się sposobem na życie. Przykładem takiej postawy jest wypowiedź niewidomego z Akwizgranu z czasów Karola Wielkiego, który swą odmowę modlitwy o przywrócenie wzroku uzasadnił tymi słowami: „Po co mi wzrok, który i tak już dawno utraciłem? Lepiej mi jest bez niego, niż byłoby mi z nim. Jako ślepiec żebrzę i nikt mnie nie odpędza, ludzie skwapliwie dbają o moje potrzeby. Gdyby wzrok mi przywrócono, brano by mi za złe, że proszę o jałmużnę" [11].

Niektórzy żebrzący przyjmowali postawę roszczeniową, wykorzystując nakaz miłosierdzia i obowiązek wspomagania potrzebujących przez chrześcijanina. Przez swą natarczywość zmuszali ludzi do dawania jałmużny, uwidaczniając cechy, które stały się powodem ich trybu życia, a nawet uciekając się do oszustwa poprzez charakteryzowanie się na niepełnosprawnych.

W średniowieczu dla najniższych warstw społecznych charakterystyczna była zmienność źródeł utrzymania - żebracy niejednokrotnie zajmowali się też kradzieżą, czasem udawało się im znaleźć dorywczą pracę. Praca, oprócz jałmużny, bywała źródłem utrzymania osób niepełnosprawnych, które najczęściej były zatrudniane w kościołach bądź przy prostych pracach w rolnictwie. Począwszy od XV w. coraz częściej władze miejskie, chcąc kontrolować liczne grupy żebrzących, zaczęły tworzyć bractwa je skupiające [12].

Rodzajem wsparcia materialnego stała się też jałmużna rozdawana niepełnosprawnym podczas seansów taumaturgicznych, czyli rzekomych uzdrowień dokonywanych przez ówczesnych władców. Do rozwoju średniowiecznej taumaturgii przyczynił się pierwowzór w postaci uzdrawiającego Chrystusa (Christus Medicus). Władcy, jako pomazańcy boży, mieli - podobnie jak Chrystus - posiadać moc uzdrawiania za pomocą dotyku. To uzdrawianie odbywało się przeważnie w czasie dni świątecznych i przybierało postać masowych widowisk, w których chorzy oraz niepełnosprawni w liczbie nawet do ok. 1000 osób dziennie zbliżali się do króla, a ten poprzez nałożenie ręki miał powodować ich wyleczenie. Pojawiła się nawet swoista specjalizacja: królowie angielscy mieli posiadać szczególne predyspozycje do leczenia epilepsji, a francuscy do gruźlicy węzłów chłonnych. Popularność tych „zabiegów” można tłumaczyć otrzymywaniem jałmużny przez osoby niepełnosprawne bądź podające się za takie. Zapewne i tutaj nie brakowało oszustów podszywających się pod chorych i mogących też udawać wyleczenie [13].

Specyficzną formą wsparcia stosowaną wobec niepełnosprawnych duchownych była w średniowieczu funkcja tzw. koaudiutora. Był on mianowanym przez biskupa diecezji pomocnikiem księży, a jego zadaniem była zarówno opieka nad niepełnosprawnym duchownym, jak i pomoc w obowiązkach duszpasterskich [14].

Na przełomie okresów średniowiecza i renesansu nastąpił kryzys opieki nad chorymi i niepełnosprawnymi. Wiązało się to z ruchami reformacyjnymi, które wpłynęły na zamykanie klasztorów i związanych z nimi szpitali. W Anglii po odłączeniu się od kościoła katolickiego przez Henryka VIII zniszczono aż 600 klasztorów [15].

\section{Trąd}

Najbardziej rozpowszechnionym i charakterystycznym dla średniowiecza rodzajem niepełnosprawności fizycznej był trąd. Wzrost zachorowań nastąpił w czasach Chrystusa, a choroba występowała powszechnie na terenie Europy do XIV w. Trąa był, oprócz dżumy, najczęściej spotykaną chorobą zakaźną, jednakże w odróżnieniu od dżumy, jako choroba przewlekła (okres jej trwania mógł wynosić kilkanaście lat) prowadził do niepełnosprawności. Uważa się, 
że oprócz przyczyn bakteriologicznych, do rozszerzania się ognisk choroby przyczynił się niski stan ówczesnej higieny.

Do objawów choroby należały: ślepota bądź wytrzeszcz oczu, zniekształcenia twarzy tzw. pysk lwa (facies leonina) i ubytki nosa czy uszu, a także zniekształcenia, paraliże, niedowłady, a nawet ubytki kończyn. Całe ciało było pokryte zmianami skórnymi, takimi jak guzy, plamy i wypryski; nierzadko występował zanik mięśni, a chorzy wydzielali też odrażającą woń.

Trędowatym przypisywano też negatywne cechy, jak gwałtowność, kłótliwość, skłonność do kłamstwa, a także wzmożony popęd płciowy. Trędowaci byli wśród niepełnosprawnych najdłużej stygmatyzowaną grupą, co mogło wynikać ze szczególnie odrażającego wyglądu osób nimi dotkniętych. Dopiero fakt, że chorobą tą zarażali się szlachetni rycerze walczący w Ziemi Świętej, będący wzorem dobrego chrześcijanina (w tym król jerozolimski Baldwin IV), spowodował złagodzenie postawy wobec ludzi nią dotkniętych.

W związku z rosnącą liczbą zarażonych konieczne stało się tworzenie tzw. leprozoriów, czyli przytułków lokowanych poza miastem, gdzie przymusowo kierowano chorych. Rozwijały się one na masową skalę. W Polsce, w której apogeum epidemii przypadło na lata 1350-1450, potwierdzono istnienie 80 leprozoriów, głównie na Pomorzu, Prusach Warmii oraz Śląsku, gdzie było duże skupisko choroby i gdzie w 1234 r. w Środzie Śląskiej powstało pierwsze leprozorium na ziemiach polskich [16].

Leprozoria były prowadzone przez zakony (bądź funkcjonowały jako oddzielne jednostki), głównie przez zakon rycerzy św. Łazarza, dla którego opieka, oprócz walki, była głównym zadaniem. W 1265 r. decyzją papieża Aleksandra IV wszystkie leprozoria znalazły się w posiadaniu lazaretów.

Do zajmowania się chorymi zgłaszali się ochotnicy (działając na zasadach dzisiejszego wolontariatu). Trędowatymi z wielkim nabożeństwem opiekowali się też średniowieczni święci, jak św. Hildegarda z Bingen, św. Katarzyna ze Sieny, św. Ludwik, św. Franciszek z Asyżu czy św. Jadwiga z Trzebnicy.

Opieka zdrowotna nad trędowatymi, sprowadzała się do ich pielęgnacji, która polegała na kąpielach (np. solnych) łagodzących dolegliwości skórne. W ramach profilaktyki ograniczano kontakty z już zakażonymi. Trądu nie tylko nie potrafiono więc wówczas leczyć, ale nie wiedziano nic na temat etiologii choroby. Ustanie epidemii trądu nie wynikało więc z zasług ówczesnej medycyny, lecz - jak się powszechnie uważa - było wynikiem pojawienia się nowej epidemii. Trąd został wyparty w XV w. najprawdopodobniej przez dżumę, która spowodowała wymieranie osób trędowatych i stopniowe zanikanie choroby.

Na specyficzny stosunek do niepełnosprawnych dotkniętych trądem i udających się do leprozorium wpłynęły: pogląd o dopuszczeniu przez Boga choroby nie tylko w przypadku grzechów, asceza, troska o życie wieczne i przekonanie o niewielkim znaczeniu życia ziemskiego, czyli wartości typowe dla średniowiecza. Trędowaci poprzez wejście do leprozorium i izolację byli uznani za umarłych dla tego świata, a jednocześnie uważani za „chorych Pana Boga”, „świętych chorych”, „męczenników Chrystusa”. Odczuwając cierpienia fizyczne, stanowili więc niejako obraz cierpiącego Chrystusa; byli wezwani do ofiarowania cierpienia za grzechy.

Wejście do leprozorium zaczynało się od mszy św. Następnie ksiądz odmawiał słowa modlitwy: „Bracie mój, biedaku drogi, kto cierpi, kto jest smutny, kto jest dotknięty chorobą, kalectwem, przeciwnościami świata, ten wejdzie do królestwa niebieskiego, gdzie nie ma już żadnej choroby, żadnej przeciwności, gdzie wszyscy są czyści i wolni od wszelkiego plugastwa. Tam i ty pójdziesz, jeśli Bóg tak zechce. Ale bądź dobrym chrześcijaninem i znoś cierpliwie te przeciwności. Niech Bóg zachowa Cię w łasce. Odosobnienie w tym domu, do którego wchodzisz, będzie tylko cielesne, duchem bowiem będziesz zawsze z nami, będziesz brał udział w naszych modlitwach. O twoich drobnych potrzebach pomyślą osoby miłosierne, Bóg Cię nie opuści. Uważaj tylko i miej cierpliwość. Niech Bóg będzie z Tobą. Amen". Mówiąc: „Umrzyj dla świata, zmartwychwstań w Bogu”, zachęcano chorych do pokory, pogodzenia się ze swoim losem, dając jednocześnie nadzieję na lepsze życie [17].

Zakażenie trądem stwierdzano na podstawie wydzielin i okruchów, które pozostawały po przecedzeniu pobranej krwi przez lnianą chustę [18]. Chorych obowiązywały zakazy dotyczące unikania kontaktu fizycznego z innymi ludźmi i pojawiania się w miejscach publicznych w celu zminimalizowania ryzyka rozprzestrzeniania się choroby: ,zakazuję ci na zawsze wchodzić do kościoła, klasztoru, młyna, przychodzić na targ, na jarmark, przebywać w towarzystwie ludzi zdrowych. Zakazuję ci wychodzić z leprozorium inaczej niż w twoim ubraniu trędowatego. Zakazuję ci myć ręce lub cokolwiek z twoich rzeczy w rzece, studni; zakazuję ci również stąd pić; jeśli chcesz wody do picia, czerp ją z twojej baryłki i tylko twoja czarką. Zakazuję ci dotykać jakiegokolwiek przedmiotu, który kupujesz lub targujesz, póty, póki nie będzie twoim. Zakazuję ci wchodzić do karczmy; jeśli chcesz wina - bądź je kupujesz, bądź ci je dają, podaj swoją baryłkę, żeby ci do niej nalano. Zakazuję ci obcować z jakąkolwiek inną niewiastą niż twoja niewiasta. Zakazuję ci, jeśli spotkasz na drodze osobę, która do ciebie chce mówić, zwracać się do niej inaczej jak pod wiatr. Zakazuję ci wchodzić w wąską uliczkę, gdzie byś mógł spotkać przechodnia, który by się musiał prawie otrzeć o ciebie. Zakazuję ci, gdziekolwiek idziesz, dotykać się studzien lub sznurów inaczej, jak w rękawiczkach. Zakazuję ci dotykać się dzieci lub dawać im cokolwiek. Zakazuję ci pić i jeść inaczej jak tylko z twoich własnych naczyń. Zakazuję ci pić i jeść w towarzystwie innych niż trędowatych" [19].

Choremu przekazywano poświęcone rzeczy osobistego użytku. Wychodzenie na ulice (niekiedy chorym pozwalano żebrać) wiązało się (podobnie zresztą jak w innych epidemiach) z założeniem odpowiedniego stroju (długi płaszcz z żółtym krzyżem, kapelusz, zasłona, maska). Chory sygnalizował swoje nadejście potrząsając grzechotkami, często też nosił ze sobą długi kij. Trędowaci, podobnie jak inni 
żebrzący, potrafili być natarczywi, co oprócz aspektu profilaktycznego, było powodem wypędzania ich z miast.

Życie w leprozoriach było zorganizowane na zasadach zbliżonych do wspólnoty klasztornej. Wniesione przez nich dobra stawały się wspólną własnością, co powodowało, że bardzo chętnie przyjmowano do nich ludzi majętnych. Chorych odosabniano, zachęcając do pokory, pogodzenia się ze swoim losem, ale dając jednocześnie nadzieje na lepsze życie po śmierci.

W średniowiecznej postawie wobec niepełnosprawnych charakterystyczna była większa wyrozumiałość wobec osób szlachetnie urodzonych. Znane są przypadki osób trędowatych niepoddawanych izolacji, jak inni chorzy. Wyjątkiem była specjalna kategoria ludzi dobrze urodzonych, znajdujących się bez środków do życia, których również wspomagano jałmużną. Oprócz wspominanego już króla jerozolimskiego Baldwina IV, byli to także Ren hrabia Vermendois i Ryszard II opat Albans [20].

\section{Podsumowanie}

W wiekach średnich w sposobie myślenia ówczesnych ludzi cały czas funkcjonowały negatywne stereotypy (mimo pojawiających się postaw miłosierdzia). Niepełnosprawność łączono z cechami negatywnymi (trąd jako herezja). Istniał też tradycyjny pogląd o chorobie jako karze za grzechy (uważano nawet, że osoby trędowate zostały poczęte w Wielkim Poście i właśnie ten fakt stał się przyczyną ich choroby) [21].

Czasem ten przekaz (patrząc $\mathrm{z}$ dzisiejszej perspektywy) przybierał formę zwykłego braku poszanowania ludzkiej godności. W zwyczaju były pokazy osobliwości, w czasie których obwożono niepełnosprawnych po jarmarkach, demonstrując rozbawionej gawiedzi. Niekiedy jednak sytuacja niepełnosprawnych fizycznie bywała tragiczna, jak w XIV-wiecznej Francji, podczas panowania Filipa $V$ po fali głodu mającej miejsce w latach 1315-1318. W związku z tym wydarzeniem chorych na trąd oskarżono o spisek i zatruwanie wody, co skończyło się dla nich torturami oraz paleniem na stosie. Chorych obciążano więc odpowiedzialnością za kataklizmy, przypisując im związki z siłami nieczystymi.

Stosunek społeczeństwa do niepełnosprawnych był zatem różny - od wrogości, poprzez obojętność, aż do miłosierdzia i pomocy. Charakterystyczny dla okresu starożytności dualizm postaw wobec niepełnosprawnych - akceptacja i piętnowanie - istniał także w średniowiecznej Europie. Los niepełnosprawnych zależał w znacznej mierze od aktualnych nastrojów społecznych i sytuacji gospodarczej.
Nowatorskie podejścia chrześcijaństwa do niepełnosprawności nie wyeliminowało co prawda tradycyjnego we wszystkich kulturach stygmatyzowania, jednak postawa wrogości pojawia się w przekazach historycznych rzadziej niż postawa miłosierdzia i wsparcia. Osiągnięciem średniowiecznej kultury było zauważenie wartości życia osób niepełnosprawnych oraz dostrzeżenie sensu niepełnosprawności, jak i cierpienia z nią związanego.

\section{Piśmiennictwo}

1. Biblia Jerozolimska. Pallotinum, Poznań 2006.

2. Brzeziński T:: Historia Medycyny. PZWL, Warszawa 2000, 109.

3. Szarszewski A.: Christus Medicus. In: Etyka w medycynie - wczoraj i dziś. Wybrane zagadnienia. Eds: K. Basińska, J. Halasz. Impuls, Kraków 2013, 15-28.

4. Kozłowski T: Stan biologiczny i warunki życia ludności in Culmine na Pomorzu Nadwiślańskim (X-XIII wiek). Wyd. UMK, Toruń 2012.

5. Sztuka M.: Jedyną właściwą szkołą chirurga jest wojna - traumatologia średniowiecznego pola bitwy. Lek Wojsk. 2011, 4 (89), 90-99.

6. Borowski G.: Sposoby wspierania osób niepełnosprawnych na przestrzeni dziejów - wybrane przykłady. Niepełnosprawność - zagadnienia, problemy, rozwiązania. 2012, 4 (5), 90-120.

7. Leś E.: Zarys historii dobroczynności i filantropii w Polsce. Prószyński i Spółka, Warszawa 2001, 20.

8. Goglin L.: Nędzarze w średniowiecznej Europie. Oficyna Wydawnicza Volumen, Dom Wydawniczy Bellona, Warszawa 1998, 57.

9. Moulin L.: Życie codzienne zakonników w średniowieczu. PIW, Warszawa 1986, 178.

10. Geremek B.: Litość i szubienica. Dzieje postaw społecznych wobec nędzy. Czytelnik, Warszawa 1989, 45.

11. Riche P.: Życie codzienne w państwie Karola Wielkiego. PIW, Warszawa 1979, 228-229.

12. Geremek B.: Człowiek marginesu w średniowieczu. In: Człowiek średniowiecza. Ed. J. Le Goff. Volumen, Marabut, Warszawa 1996, 459.

13. Seyda B.: Dzieje medycyny w zarysie. PZWL, Warszawa 1973 93-94.

14. Garbat M.: Rehabilitacja zawodowa osób z niepełnosprawnościami do końca XIX wieku. Niepełnosprawność - zagadnienia, problemy rozwiązania. 2013, 4 (9), 67-93.

15. Nawrocka A.: Etos w zawodach medycznych. Wyd. WAM, Kraków 2008, 104.

16. Kumor B., Obertyński Z.: Historia kościoła w Polsce. Pallotinum, Poznań-Warszawa 1974, 1, 1, 280.

17. Szumowski W: Historia medycyny. PZWL, Warszawa 1961, 164-165.

18. Rabęcka-Brykczyńska J.: Leprozoria w średniowiecznych miastach polskich. Studia i Materiały z Historii i Kultury Materialnej”. Warszawa 1989, 61, 56.

19. Trąd (lepra). Leczenie-objawy.pl, http://leczenie-objawy.pl/trad.htm (12.01.2014).

20. Le Goff J.: Kultura średniowiecznej Europy. Wolumen, Warszawa 1995,322

21. Le Goff J., Truong N.: Historia ciała w średniowieczu. Czytelnik, Warszawa 2006, 92 . 